\title{
Window-dressing in German interwar balance sheets
}

\author{
Mark Spoerer
}

University of Hohenheim

Dept. of Economics and Social Sciences

Dept. 570A

D-70593 Stuttgart

Germany

spoerer@uni-hohenheim.de
April-July 1998

Universitat Pompeu Fabra

Dept. of Economics

Ramon Trias Fargas, 25-27

E-08005 Barcelona

Spain

mark.spoerer@econ.upf.es 


\title{
Window-dressing in German interwar balance sheets
}

\begin{abstract}
German accounting rules value assets and liabilities asymmetrically and thus lead to grossly distorted balance sheets. In the interwar debate on a reform of disclosure regulation, financial experts considered the (undisclosed) tax balance sheet, which had to be drawn up separately for the corporate tax assessment, as a paradigm for adequate financial disclosure. However, due to tax secrecy they were barred from analyzing tax documents. Using archival evidence, we analyze tax balance sheets from which the reliability of disclosed balance sheets of the interwar period can be assessed. It emerges that companies overstated their profits in the midand late 1920s, but grossly understated them in the Nazi economy.
\end{abstract}

JEL: N24

Keywords: Germany, accounting history, window-dressing, tax balance sheet 


\section{Introduction}

In March 1993 the German automobile concern Daimler-Benz disclosed a decision that immediately was considered as a milestone in German financial history. The company had decided to list its shares on the New York Stock Exchange (NYSE) and thus was the first German firm to accept the US-GAAP accounting standards. Although many other German firms would like to list their shares on NYSE as well, few have followed Daimler's example so far. In contrast, senior executives of concerns like Bayer and Mannesmann publicly criticized Daimler for 'bending' to the Americans. The main reason for this attitude is that

'German firms are obsessed with conservative accounting, and their standards allow managers to hide huge reserves on balance sheets without telling shareholders. [...] They fear greater disclosure and less conservative accounting will expose them to increased pressure from disgruntled investors. Most German managers still prefer the quiet life, even if that means giving New York a miss.' (Economist, 1994: 83)

Hence financial analysts still have difficulties to assess the economic performance of German firms. This tradition of insufficient financial disclosure has affected German business historiography as well. Since German balance sheets are notorious for their unreliability, most authors shy away from financial issues.

This paper tries to show a way out of this dilemma, at least for the interwar period, and possibly for the 1950s and early 1960s as well. In the following section I summarize the arguments why the German disclosed balance sheet is an unreliable source. In the subsequent section I introduce the (undisclosed) tax balance sheet, a source not used by business or economic historians until very recently. The size of the gap between valuation in the disclosed and the tax balance sheets is shown by comparing the profitability of a sample of 106 industrial firms, with amazing results for the Nazi era. The last section concludes. 


\section{Window-Dressing in German Disclosed Balance Sheets and Why (Nearly) Everybody}

\section{Was Happy With It}

Until 1969 only public limited companies (Aktiengesellschaft, abbreviated AG, corresponds to a plc) were obliged by law to disclose their balance sheet and profit and loss account annually. Only a small fraction of German firms has chosen this legal form, but since the early 1920s most large enterprises are among them (Siegrist, 1980: 92). The disclosure of a plc's annual balance sheet had already been stipulated in a Prussian corporation act of 1856 , whereas accounting regulations that deserve the name did not start before 1884. Those for plcs were transferred from the Commercial Code to the Stock Corporation Law of 1937 (Barth, 1953: 65-113, Hanf, 1978, Schneider, 1995).

Until 1931, the layout of the balance sheet was not stipulated. Part of the government's emergency decrees in September 1931 was a reform of the Commercial Code (Quick, 1991). Since then, the layout of the German balance sheet does not differ much from its Anglo-Saxon counterparts (Table 1).

[Insert Table 1 about here]

However, the reform of 1931 did hardly touch upon the manifold opportunities of the Commercial Code to undervalue assets or overvalue accrued liabilities which were the main problem for contemporary financial analysts, and thus for today's business historians as well. Among these opportunities, two methods stand out, undervaluation of tangible assets, financial assets and inventories on the one hand, and disclosure of reserves as provisions on the other.

The most extreme undervaluation of tangible assets and inventories was simply not to capitalize them, which was often practiced in the $19^{\text {th }}$ century but considered as deceit in the $20^{\text {th }}$ century. However, it was not explicitly illegal until the reform of 1931 (Brandt, 1933: 31). There were more subtle methods to hide profits anyway. More popular among stock 
corporations was to capitalize new assets and then to write them off in large parts, which was in principle limited only by their historical costs. That is, until the Stock Corporation Law of 1965, new assets could be written off immediately to a pro memoria item of 1 Reichsmark (RM). Table 2 shows how large the legal options to undervalue were.

\section{[Insert Table 2 about here]}

These regulations even could coerce firms to build up hidden reserves. E.g., if real estate or share prices increased over the costs of acquisition, the firm was not allowed to take account of this. In contrast, a decrease under the costs of acquisition required corresponding writeoffs. This so-called imparity principle, which requires unrealized losses to be accrued but prohibits recognition of unrealized profits, is still in effect today (Macharzina, 1981, Coenenberg, 1997: 42).

German firms were notorious for taking advantage of these opportunities (Lurié, 1947: 122-7, Pohl, 1985). The chemical firm Beiersdorf, more known for their brand names Nivea, Hansaplast and Tesa, disclosed the following balance sheet for the financial year 1934 (Table $3)$.

[Insert Table 3 about here]

Not only was superdepreciation common practice in German balance sheets, disclosing fixed assets of nearly zero even was regarded as expression of solid management. In contrast, open reserves met suspicion (Lion, 1927: 13, Prion, 1931: 27, Rosendorff, 1932: 100).

The other commonly used way to hide profits was the declaration of reserves as provisions, that is overvaluation of accrued liabilities. Apart from actually earned profits, there was principally no limit to this practice. Hoesch AG, one of Germany's largest iron and steel producers, disclosed two provision items, Rückstellungen I and Rückstellungen II. Only insiders - auditors, tax authorities and large stakeholders such as the Deutsche Bank (both 
shareholder and creditor) - knew that most items summarized in Rückstellungen I simply were hidden reserves (Bundesarchiv, P 1233, internal memo Deutsche Bank 10/08/1936, and Hoesch-Archiv, Konzernprüfungen). Table 4 shows the development of Hoesch's disclosed reserves, 'provisions' and net income from 1935/36-38/39.

\section{[Insert Table 4 about here]}

The conspicuous correlation between disclosed net income and dividends was typical for the balance sheets of the mid and late 1930s. In 1934, the government had restricted the dividends paid out in cash to a dividend rate of 6 per cent (in some cases 8 per cent). Dividends beyond this threshold were tolerated but had to be paid to a blocked account. Most firms shied away to do so and sticked to the $6 / 8$ per cent threshold. Shareholders were also skeptical whether they would ever receive blocked dividends and thus approved to the firms' cautious profit disclosure. ${ }^{1}$

Window-dressing was by no means confined to the Nazi era, as the two foregone examples might suggest. A wondering American academic noted in 1929:

'In ordinary German business practice the published balance sheet is regarded as being just as appropriate a field for the exercise of executive policy as any other part of the company's activities. The management submits only what it thinks is proper for the stockholders and the general public to know, and its presentation often has little to do with the real state of the facts. This is not regarded as an immoral deception; it is the customary convention [...].' (Angell, 1929: 232)

It has to be stressed once more that the practices described above were fully in line with existing law. From the perspective of the legislators, the rationale for asymmetric accounting rules was the principle of creditor protection. Firms should be allowed to make themselves look poorer than they actually were, but not vice versa. ${ }^{2}$ This was a consequence of the

1 Their distrust was partially justified: the blocked dividends were released not before 1941, and with a discount of 17.5 per cent. Hence shareholders faced a retrospective supertax on dividends (Spoerer, 1996: $85)$.

2 Of course, an existing stock of hidden reserves built up in the past is ideal to hide current losses as well. Contemporaries were well aware of this, but the argument was not sufficient against the vested interests which protected the status quo. 
experiences of the Gründerkrise in the mid-1870s, when many newly-founded, unsolid plcs had gone bankrupt.

Seen over a longer period, hidden reserves in most assets are dissolved automatically. Hence it is often argued that hidden reserves are simply a shift of disclosed profits over time and that the effect is not more than smoothing. However, this argument does not hold for reserves in assets which do not or not necessarily depreciate, such as land and financial assets. Moreover, profits hidden in provisions might be carried over as long as the firm exists. Thus hidden reserves may not only distort the disclosed financial status in the short run, but in the long run as well.

Why did shareholders, who formally decided which part of the profits should be distributed as dividends (though severely constrained to do so by the Stock Corporation Law between 1937 and 1965), did not exert stronger pressure on firms to improve their financial disclosure standards, or the legislative to change the law? It has never been satisfactorily explained why, but it is regarded as a well-established fact that German firms relied strongly on the intermediation of banks rather than on raising funds directly from the public (Hardach, 1984, Pohl, 1985, Tilly, 1995, Da Rin, 1996). Thus German banks traditionally played a much larger role in non-banks than in the Anglo-Saxon business world (see for a positive evaluation Benston, 1994, for critical ones Edwards and Fischer, 1994, and for a different view Edwards and Ogilvie, 1996). To protect their large stakes or credits, the banks sent one or more senior executives to the supervisory board (Aufsichtsrat) which looked after the managing board (Vorstand). In addition, the banks were vested with the proxy voting rights of many small shareholders. The mighty banks' delegates in the supervisory board insisted on being and were regularly informed about the financial status of the firm by means of confidential reports, as in the case of Hoesch reported above. ${ }^{3}$ Hence the small group of the most important stake-

\footnotetext{
3 Many other examples can be found in the copies of the Deutsche Bank files in Bundesarchiv, 80 Ba 2.
} 
holders got the information it required and saw no need to share it with the ordinary shareholder. As a consequence, both industrial plcs and banks formed a powerful lobby which impeded any significant improvement of accounting regulations until today. It is not pressure from the still uninfluential German non-institutional shareholder which has started to change things since 1993, but the demand of German multinationals for financial funds from the international capital markets and hence the need to adapt to their disclosure standards.

This antagonism of non-institutional shareholders on the one hand and the cosy alliance of Vorstand and bank representatives in the Aufsichtsrat on the other is of course a typical principal-agent-problem based on the impossibility for the principal to get full information on the actions and performance of the agent. This asymmetry of information and power finds its best expression in a sentence ascribed to Carl Fürstenberg, one of Germany's leading bankers in the late Empire: 'Shareholders are both stupid and impudent, stupid because they give away their money, and impudent, because in addition they want dividends' (Schwerin v. Krosigk, 1958: 646-7, my translation).

\section{The Tax Balance Sheet as an Alternative to the Disclosed Balance Sheet}

To be sure, non-institutional shareholders did struggle for better financial disclosure. AEG, then the other large electrotechnical concern besides Siemens, was sued at least twice because of its policy of accruing large hidden reserves - but won (Ausschuß, 1928: 399). After WWI, the shareholders found influential allies. Whereas most lawyers were proponents of the principle of creditor protection, and thus hidden reserves, the growing number of business economists pleaded for a reform of accounting regulations in favor of more transparency. This group had just succeeded in establishing its profession within the universities and received increasing public interest and appreciation in line with the contemporary enthusiasm for rationalization, which gave accounting a boom (Nolan, 1994: 133-7). 
The proponents of a reform for more transparent balance sheets were quickly at hand with a feasible alternative to the asymmetric valuation principles ruling the disclosed balance sheet. Following the tax reforms of 1925, every German firm had to draw up another balance sheet, the income/corporate tax balance sheet for the income/corporate tax assessment. There is a certain irony in the fact that the very legislator who proponed the principle of creditor protection in the commercial law was not willing to accept the balance sheet when it came to collecting taxes. Precisely because firms could hide profits in the disclosed balance sheets, the tax laws of 1925 initiated what soon was called the Steuerbilanz (tax balance sheet). In contrast to its predecessors ${ }^{4}$, the tax balance sheet created in 1925 was subjected to rigid accounting rules which included comparatively realistic depreciation rates, a clear distinction between reserves and provisions and the like. Moreover, the tax balance sheets of medium and large size firms were closely audited at least every three years. As the tax law was constrained by the principle of fair taxation, the valuation principles of the tax balance sheet were aligned to precisely what shareholders and business economists argued for, the 'true' financial status (Gebhardt, 1938, Nowak, 1938: 77, 92-3, Schneider, 1978: 346). Hence they presented the tax balance sheet as a paradigm for 'true balance sheets' - thus the title of a paradigmatic book by Lion (1927) and an article by Helpenstein (1936). Yet, their efforts to adapt the valuation principles underlying the disclosed balance sheet to those of the tax laws were in vain. In contrast, the reform of the Commercial Code in 1931 unequivocally tolerated the practice of hidden reserves, and the Stock Corporation Law of 1937 even encouraged it.

Although many of the pro-reformers were practitioners who had access to tax balance sheets, their arguments were purely theoretical: the tax balance sheet was not disclosed and has never been used in empirical work until very recently (Schröder, 1996, Spoerer, 1995,

\footnotetext{
4 The beginnings of the tax balance sheet go back to at least 1853, see Schneider (1995: 133).
} 
1996). ${ }^{5}$ Principally, tax balance sheets might be found in company archives and in public archives. In general, German firms are not very keen on allowing access to tax data. However, Hoesch, Krupp, Mannesmann, Thyssen, names that stand for Weimar's reactionary heavy industry, follow a liberal archive policy today, whereas Dyckerhoff (concrete), Schultheiss (brewing) and Siemens (electrical engineering) explicitly deny access to their files. ${ }^{6}$ The question of access to documents in public archives, normally unproblematic in Germany, is similar inconsistent. Whereas the German Federal Archive admits access to tax records, state archives in West Germany - with the exception of Lower Saxony - and former West Berlin keep them classified for 80 years. Archives in East Germany and former East Berlin admit access without any problems.

The contemporary tax literature and the archival material allow to assess the reliability of the tax balance sheet as a source for a firm's financial status. The valuation of assets and liabilities in the tax balance sheet was in fact much more rigid and realistic than that of the commercial balance sheet. Normally, large legal hidden reserves in the tax balance sheet could accrue only in the case of windfall profits stemming from loans in foreign currency which had devalued, a rare case.

Naturally, industry was not happy at all with the much restricted scope for 'balance sheet policy', i.e. window-dressing, in the tax balance sheet compared to the disclosed balance sheet. Industrial lobbyists opposed to the strict application of linear depreciation in the tax balance sheet, and a ruling of the Fiscal High Court (Reichsfinanzhof) in December 1928 led to a revision in their favour. As a consequence, an immediate write-off of 20 per cent on fixed

5 With the exception of three contemporary studies carried out by the Reichsverband der Deutschen Industrie (RDI, Industry Federation): Tetzlaff et al. (1927), Skrodzki and Moessner (1929) and Skrodzki (1934). The reason why the RDI used confidential tax balance sheets provided by member firms instead of easily accessible disclosed balance sheets was precisely that 'the figures derived by the tax balance sheets [...] are without doubts closer to reality' (Skrodzki, 1934: 11, my translation). This did not prevent the RDI from publicly opposing the allegedly too low tax depreciation rates, see Walb (1930).

6 The case of Siemens is hard to understand, as the head of its archive precisely quotes the documents to which he denies access, see Feldenkirchen (1995: 632, 636). 
assets was granted for the first year, retroactively from 1928 (Schröder, 1996: 62-9). As the German economy slid into the crisis as early as in the beginning of 1929, and profits with it, the opportunity of an immediate write-off of 20 per cent came at the wrong time and thus presumably had little impact. The disastrous situation of public finances in the slump put an end to this allowance in 1931.

A more important turning point was the taxation policy starting 1934. The Nazi regime had the capital market under tight control and did not want to compete for funds on it with industry (Barkai, 1990: 204-7). However, industry's financial demands had somehow to be met, and for that reason the regime alleviated self-financing by a number of measures. Part of it were immediate full tax write-offs introduced in 1934 for machinery with a normal operating life of five years or less. Due to the good profitability situation of most industrial firms, this opportunity was widely used. Hence from 1934 onwards, significant hidden reserves could be accrued in the tax balance sheet as well. As a consequence, tangible assets and net income are understated in the tax balance sheets, though still in much smaller scale than in the disclosed balance sheets. In 1937, this allowance was repealed, but a similar one was introduced in 1939, though not as generous as its predecessor (Spoerer, 1996: 93-5).

The tax audits were very rigid and extremely unpopular among the firms, often resulting in legal action and sometimes escalating to severe conflicts between large firms and the fiscal administration, under the Nazi dictatorship as well as in the Weimar democracy, and even during World War II. For example, in a confidential report to a senior executive of Deutsche Bank, the chairman of Hoesch's managing board listed the two most desastrous events of the financial year 1941/42: firstly, the tax audit, secondly the detriments from an air raid (Bundesarchiv, P 1236, Hoesch to Deutsche Bank, 11/24/1943).

Three examples might illustrate how far the valuation in the tax balance sheet deviated from that in the disclosed balance sheet. In Table 4 above, the discrepancy between lines (iv) and 
(vi) shows what financial analysts of the Deutsche Bank called an 'extraordinarily prudent accounting policy' (Bundesarchiv, P 1233, Deutsche Bank memo 02/04/1935, my translation). For the Mitteldeutsche Stahlwerke AG, another leading iron and steel group which was in the hands of Friedrich Flick (sentenced in the Nuremberg war crime trials 1947), common financial ratios look very different if calculated from the disclosed balance sheets, or from the tax balance sheets (Table 5).

\section{[Insert Table 5 about here]}

As can be seen from the ratios derived from the tax balance sheets, the firm disclosed profits in the second half of the 1920s which it had not earned, in other words, the dividends were paid out of substance. After a clear cut in the tax balance sheet of 1931/32, things began to improve in the 1930s. The armaments programs of the Nazi regime fueled the order books, and profitability increased enormously from the financial year 1934/35 onwards. However, this was only partially reflected by the disclosed balance sheets which showed a much more modest pattern (for a more detailed discussion see Spoerer, 1995).

An even more extreme case is Fried. Krupp AG, a family firm which did not need to bother about outside shareholders. In the course of the allied war crime investigations against Krupp, the head of the accounting department explained in October 1945:

'Column No. [i] represents the profits as shown in the published commercial balance sheet following the decisions of the Vorstand and Aufsichtsrat, which was at the shareholders' disposal. These profits were arbitrarily fixed by the Vorstand and the Aufsichtsrat after deduction of reserves fixed by them and do not represent the actual profits of the company [...]. The calculation of the reserves was left to the discretion of the Vorstand and the Aufsichtsrat. The account of the free reserves made it possible to reduce the published profit to the amount which the Vorstand and Aufsichtsrat wished to publish. According to German stock laws this is permissible and was generally handled in this way [...].

Column No. [ii] represents the net-profits after deduction of taxes and depreciations acknowledged by the tax authorities.' (Historisches Archiv Krupp, WA 40/339, p. 8).

[Insert Table 6 here] 
Obviously, Krupp's disclosed balance sheets were a farce.

\section{Empirical Analysis of Tax Balance Sheets}

These examples raise the question how widespread window-dressing was. Was it confined to few well-earning companies, or was it a common phenomenon? Table 7 shows the results of a larger study carried out for mid- and large sized industrial plcs.

\section{[Insert Table 7 about here]}

Table 7 contrasts 637 disclosed balance sheets of 106 industrial ples with their tax balance sheet counterparts, that is same firm and same financial year. The sample firms are either active in the capital or in the consumer goods industry, with mining firms included in the former due to large integrated coal, iron and steel concerns. ${ }^{7}$ Cols (ii) and (vi) are the profit rates calculated by dividing profit (including changes in reserves) and equity (including reserves) of the disclosed and the tax balance sheet, respectively. Cols (iii) and (vii) are the standard deviations. Whether a correlation between profitability and firm size (here measured by highly correlated equity as we lack data on the tax balance sheet totals for some firms ${ }^{8}$ ) exists is indicated by the correlation coefficients in cols (iv) and (viii), and whether they are significant on conventional levels by the t-statistics in cols (v) and (ix). The periods considered are 192529, the so-called golden years of the Weimar Republic, 1933-35 as the first years of recovery under the Nazi regime, and 1936-41, the years of intensified armaments production and war. Data for the years after 1941 are unreliable, as these years' balance sheets were audited at a time when it was clear that the war would be lost, or even after the defeat. In the years 193032 the firms' financial results were so disastrous that the fiscal administration often did not

7 Distribution of sample firms within the industrial branches as classified by the German statistical office: mining and metallurgy (15), building materials (1), iron, steel and nonferrous metals (8), paper (2)*, pottery and glass $(5)^{*}$, metal hardware (5), mechanical engineering and vehicles (20), electrical engineering (6), precision mechanics and optics (1), chemicals (17), textiles $(8)^{*}$, printing $(1)^{*}$, leather and linoleum $(0)^{*}$, caoutchouc and asbestos (1), timber and woodworking $(0)^{*}$, musical instruments and toys $(0)^{*}$, food, beverages and tobacco $(16)^{*}$, clothing and shoewear $(0)^{*}$. Branches indicated with an asterisk are classified as part of the consumer goods industry. 
bother to assess their (negative) incomes. For 1930 and 1931, the Treasury did not even publish the usual, quite detailed statistical surveys on corporate tax revenues.

The period from 1925-29, between hyperinflation and stabilization 1923/24 and the world slump starting in late 1929 , is regarded as a comparatively prosperous period. However, a comparison of the profitability calculated from the tax data to profitability calculated from the disclosed data shows that industrial profitability was low, and that the firms disclosed paper profits. For example, Vereinigte Stahlwerke AG, then Germany's largest industrial concern, disclosed far higher profits in the disclosed balance sheets than were actually earned. Apart from obvious domestic reasons to do so, there were international considerations. Due to high domestic interest rates, the firm had to compete for funds on the international capital markets, especially in the U.S., where it placed large loans. Had Vereinigte Stahlwerke issued dividends even lower than the modest 6 per cent it actually paid, foreign investors would have questioned not only this firm's creditworthiness, but that of the industry as a whole (Thyssen-Archiv, VSt/4258).

Yet, most contemporary experts did not believe that industry's laments over low profitability were justified. Precisely because of the manifold opportunities to hide profits in the disclosed balance sheets, they assumed that industrial profitability was much higher than the quite mediocre rates of around 4 per cent which appeared in statistical surveys on balance sheets compiled by the Reich's statistical office (Statistisches Jahrbuch für das Deutsche Reich, 1926-31). In contrast, the tax data in col. (vi) even suggest lower profit rates, especially in the capital goods industry. This confirms the pessimistic assessment of the overall economic performance of Weimar's industry as expressed by a rising number of economic historians (Borchardt, 1990, Broadberry and Ritschl, 1995). The suspicion of window-dressing in the

8 See footnote to Table 8 below. 
disclosed balance sheets, especially profit smoothing, is supported by the lower standard deviations in col. (iii) as compared to col. (vii).

In the 'Third Reich' industrial profitability increased enormously, much more than was necessary for mere self-financing purposes and to an extent that the German joint-stock banks increasingly lost influence over their flourishing industrial customers (Barkai, 1990: 213-15). Col. (vi) illustrates this increase of profitability very clearly. Note that, as super depreciations of machinery were tolerated in the tax balance sheet from 1934 to 1937 (see above), these figures even tend to understate actual profitability. As industry's cash-flow was sufficient even to pay back long-term debts, it is doubtful whether the regime, which had all important economic sectors in tight grip (Abelshauser, 1998), had just self-financing of industry in mind. Moreover, the high profits of the capital goods industry might be interpreted as a kind of 'political premium' to the armaments industry paid by the regime which was impatient to realize its ambitious armaments and war programs (Spoerer, 1996). ${ }^{9}$

However, the disclosed balance sheets looked totally different. Both the dividend restrictions introduced in 1934 and the Stock Corporation Law of 1937 led many firms to disclose profits of just the amount what they distributed as dividends. Again, it is especially the capital goods industry which shows the highest deviations between disclosed and actual profitability. However, whereas in the Weimar years the firms, especially in the capital goods industry, concealed their low profitability, they now were not keen to disclose their high profits - the regime was neither, because of its anti-capitalist propaganda. Again, the much lower standard deviations of the capital goods industry's disclosed profitability show profit smoothing on large scale.

9 The dividend restrictions did not have much impact. Despite of the mediocre dividends, industry share prices increased strongly to an average of c. 180 per cent (of face value) at the end of 1940 (Statistisches Jahrbuch für das Deutsche Reich, 1941/42). 
As col. (viii) shows, their was no significant correlation between firm size and profitability until the mid-1930s. However, medium sized firms in the capital goods industry were slightly more profitable than large size firms in 1936-41. This is in striking contrast to the oftenrepeated assertion that 'big business' profited most from the Nazis. ${ }^{10}$ In the Weimar Republic, there seems to have been a negative correlation between profitability and firm size in the consumer goods sector, but not on a conventionally significant level.

Table 7 illustrates actual profitability, but it is not always straightforward to assess from it in how far working for the armaments industry or firm size had an impact on financial disclosure behaviour. Moreover, one might speculate that disclosure might also have been affected by whether a firm's shares were listed at the stock exchange or not. In order to test this, we estimate the following model for the 106 sample firms in the periods 1925-29, 1933-35 and 1936-41:

$$
\pi_{\mathrm{D}}-\pi_{\mathrm{T}}=\alpha+\beta_{1} \log \left(\text { equity }_{\mathrm{T}}\right)+\beta_{2} \text { listed }+\beta_{3} \text { capgoods }+\varepsilon \text {. }
$$

The dependent variable is the deviation of the disclosed $\left(\pi_{\mathrm{D}}\right)$ from the 'true' tax profit rate $\left(\pi_{\mathrm{T}}\right)$. The independent variables are equity of the tax balance sheet as a proxy for firm size (see note to Table 8), a dummy variable which takes the value of 1 if the plc was listed on a German stock exchange, and 0 otherwise, and another dummy variable which takes the value of 1 if the firm's main activities were focused on the capital goods industry, and 0 otherwise.

For the periods 1925-29 and 1933-35, no combination of these variables leads to coefficients which are significant even on the 10 per cent level. That is, neither firm size nor being listed at the stock exchange is significantly correlated with under- or overstating profitability. However, in the Nazi period things changed. Table 8 gives the results for the years of war preparation and the first years of World War II.

10 E.g., Temin (1991: 580). Note that the sample is confined to plcs (Aktiengesellschaften), i.e. medium and large sized firms. During the war, the Nazis dissolved many small firms simply by decree. 
[Insert Table 8 about here]

Given the results of Table 7, it does not surprise that being active in the capital goods industry had a strong impact on a firm's disclosure of profitability: 'true' profitability is on average understated by 6.5 per centage points and producing for the capital goods industry adds another eight to nine percentage points in all three specifications of the model. Specifications (2) and (3) take account of the fact that firm size and being listed on the stock exchange are strongly correlated. From col. (2) it turns out that firm size had a negative and significant impact on the amount of misstating profits: the larger a firm was, the less did it understate profits. This is not surprising: small and medium sized firms were more profitable, as we know from Table 7. In contrast, whether a firm's shares were traded at the stock exchange did not affect financial disclosure in respect to profitability. To sum up: in the period of war preparation and war, there was a strong tendency among German joint stock companies to understate their high profitability in the disclosed balance sheets, all the more if the firm was active in the armaments industry and the smaller it was.

\section{Conclusion}

In the course of the industrialization process, the institutional balance of the German capital market developed in a very different manner than its Anglo-Saxon counterparts. This led to a different culture of financial disclosure as well. The informational needs of a small group of stakeholders, especially Berlin's influential universal banks, was satisfied by confidential reports, whereas non-institutional shareholders and the public were put off with balance sheets whose only purpose was to justify the dividends, as contemporary critics mourned (Prion, 1927: 24).

In the interwar discussion about a reform of accounting regulation, the tax balance sheet was regarded as a paradigm for a 'true' balance sheet. Notwithstanding the question whether a 'true' balance can exist at all, we have seen that the tax balance sheet was indeed much more 
realistic than the disclosed balance sheet, despite some qualifications especially from 1934 onwards.

Using tax balance sheets as a benchmark, it emerges that German firms - more precisely: medium and large-sized industrial ples - smoothed profits throughout the interwar period. In the mid- and late 1920s, they disclosed paper profits, in contrast to what most contemporary observers believed. During the Nazi economic recovery, German industrial firms earned enormous profits which were understated in the disclosed balance sheets. The capital goods industry profited most from the Nazi's armaments programs, and hence we find the strongest diversion between (high) actual profits and (mediocre) disclosed profits in their balance sheets. Neither the regime nor the firms were keen on disclosing true profitability. Contemporary observers were aware of this, and non-institutional shareholders were partially compensated by increasing share prices. However, they lacked adequate information for their portfolio decisions. Thus window-dressing served the interests of the firms' management, the banks and the regime, to the detriment of non-institutional shareholders and the public.

It would be interesting to extend this analysis to post-WWII West Germany. According to Schneider (1978: 346), the notion of income in the tax laws then was still quite close to that in economics. However, from the 1960s onwards the policy of granting subsidies via taxation dilutes the comparatively realistic character of the tax balance sheet.

It is difficult to assess in how far the German experience might be carried over to other countries. For economies with a vivid stock market culture the problem of window-dressing balance sheets may not arise in the first place, or not as intensely as in the German case. But the capital markets of most European countries resembled more the German than the AngloSaxon model (Teichova et al., 1994, Tilly, 1995), and their governments must have been as keen on tax revenues as the German. Thus, the two most important factors which led to a 
separate and more realistic tax balance sheet in Germany can be found in other countries as well.

\section{References}

Bundesarchiv, Koblenz and Berlin P 1233, P 1236, 80 Ba 2.

Hoesch-Archiv, Dortmund Konzernprüfungen IV and V

Krupp-Archiv, Essen WA 40/339

Sächsisches Hauptstaatsarchiv, Dresden Mitteldeutsche Stahlwerke, Nos 12.323, 12.36612.368

Thyssen-Archiv, Düsseldorf VSt/4258

Abelshauser, Werner (1998) 'Germany: guns, butter, and economic miracles', in Mark Harrison (ed.) The economics of World War II: six great powers in international comparison, Cambridge: Cambridge University Press, pp. 122-76

Angell, James W. (1929) The Recovery of Germany, New Haven: Yale University Press Ausschuß zur Untersuchung der Erzeugungs- und Absatzbedingungen (1928) Wandlungen in den Rechtsformen der Einzelunternehmungen und Konzerne, Berlin: Mittler

Barkai, Avraham (1990) Nazi Economics. Ideology, Theory, and Policy, Oxford et al.: Berg Barth, Kuno (1953) Die Entwicklung des deutschen Bilanzrechts und der auf ihm beruhenden Bilanzauffassungen, vol. I: Handelsrechtlich, Stuttgart: Selbstverlag

Benston, George J. (1994) 'Universal Banking', Journal of Economic Perspectives, 8 (3): 121-43

Borchardt, Knut (1990) 'A Decade of Debate About Brüning's Economic Policy', in Jürgen von Kruedener (ed.) Economic crisis and political collapse: the Weimar Republic, 19241933, New York et al.: Berg, pp. 99-151

Brandt, Emil (1933) Die Aktienrechtsreform in der Praxis, 2nd edn, Berlin: Heymann Broadberry, Stephen N. and Albrecht O. Ritschl (1995) 'Real Wages, Productivity, and Unemployment in Britain and Germany during the 1920s', Explorations in Economic History, 32: $327-49$

Coenenberg, Adolf G. (1997) Jahresabschluß und Jahresabschlußanalyse, 16th edn, Landsberg/Lech: Verlag Moderne Industrie

The Economist, September 17, 1994, p. 83

Da Rin, Marco (1996) 'Understanding the development of the German Kreditbanken, 18501914: an approach from the economics of information', Financial History Review, 3: 29-47

Edwards, Jeremy and Klaus Fischer (1994) Banks, finance and investment in Germany, Cambridge: Cambridge University Press

Edwards, Jeremy and Sheilagh Ogilvie (1996) 'Universal banks and German industrialization: a reappraisal', Economic History Review, 49: 427-46

Feldenkirchen, Wilfried (1995) Siemens 1918-1945, Munich et al.: Piper

Gebhardt, Joseph (1938) 'Die stillen Rücklagen', in Fritz Reinhardt (ed.) Handbuch der steuerlichen Betriebsprüfung, vol. 2, Berlin et al.: Spaeth \& Linde, pp. 108-27

Handbuch der deutschen Aktiengesellschaften, various issues, Berlin: Hoppenstedt Hanf, Reinhardt (1978) 'Veröffentlichte Jahresabschlüsse von Unternehmen im deutschen Kaiserreich. Bedeutung und Aussagewert für wirtschaftshistorische Analysen', Zeitschrift für Unternehmensgeschichte, 23: 145-72 
Hardach, Gerd (1984) 'Banking and Industry in Germany in the Interwar Period 1919-1939', in Banks and Industry in the Interwar Period (The Journal of European Economic History. Special Issue), Rome: Banco di Roma, pp. 203-34

Helpenstein, Franz (1936) 'Wahre Bilanzen', Zeitschrift der Akademie für Deutsches Recht, 3: $976-84$

Lion, Max (1927) Wahre Bilanzen! Ein Beitrag zur Vereinheitlichung von Handelsbilanz und Steuerbilanz, Berlin: Heymann

Lurié, Samuel (1947) Private Investment in a Controlled Economy. Germany, 1933-1939, New York: Columbia University Press

Macharzina, Klaus (1981) 'Financial Reporting in West Germany', in Christopher Nobes and Robert Parker (eds) Comparative International Accounting, Deddington: Allan, pp. 123-59 Nolan, Mary (1994) Visions of Modernity: American Business and the Modernization of Germany, New York et al.: Oxford University Press

Nowak, Alexander (1938) Handelsbilanz und Steuerbilanz, Zurich et al.: Verlag für Recht und Gesellschaft

Pohl, Hans (1985) 'Forms and Phases of Industry Finance up to the Second World War', in German Yearbook on Business History 1984, Berlin et al.: Springer, pp. 75-94

Prion, Wilhelm (1927) 'Finanzierungsfragen der Gegenwart', in Finanzierung, steuerrechtliche Gewinnermittlung, Selbstkostenrechnung, Wirtschaftsberatung, Leipzig, pp. 5-29

Prion, Wilhelm (1931) Selbstfinanzierung der Unternehmungen, Berlin: Springer Quick, Reiner (1991) 'Die Entstehungsgeschichte der aktienrechtlichen Pflichtprüfung in Deutschland', Zeitschrift für Unternehmensgeschichte, 37: 217-36

Rosendorff, Richard (1932) Was müssen die Aktionäre und Verwaltungen vom neuen Aktienrecht wissen?, Berlin et al.: Spaeth \& Linde

Schneider, Dieter (1978) 'Erfolgsermittlung als Rechnungsziel - ein empirischer und wissenschaftsgeschichtlicher Test', Zeitschrift für betriebswirtschaftliche Forschung, 2nd ser., 30: 326-47

Schneider, Dieter (1995) 'The history of financial reporting in Germany', in Peter Walton (ed.) European Financial Reporting. A History, London et al.: Academic, pp. 123-55

Schröder, Susanne (1996) Steuerlastgestaltung der Aktiengesellschaften und Veranlagung zur Körperschaftsteuer im Deutschen Reich und den USA von 1918 bis 1936, Berlin: Duncker \& Humblot

Schwerin v. Krosigk, Lutz (1958) Die große Zeit des Feuers. Der Weg der deutschen Industrie, vol. 2, Tübingen: Wunderlich

Siegrist, Hannes (1980) 'Deutsche Großunternehmen vom späten 19. Jahrhundert bis zur Weimarer Republik. Integration, Diversifikation und Organisation bei den hundert größten deutschen Industrieunternehmen (1887-1927) in international vergleichender Perspektive', Geschichte und Gesellschaft, 6: 60-102

Skrodzki, Bernhard (1934) Die Steuer- und Soziallast der Industrie in der Krise, Berlin: Reichsstand der Deutschen Industrie

Skrodzki, Bernhard and Karl E. Moessner (1929) Besteuerung, Ertrag und Arbeitslohn industrieller Unternehmungen im Jahre 1927, Berlin: Reichsverband der Deutschen Industrie

Spoerer, Mark (1995) "Wahre Bilanzen!" Die Steuerbilanz als unternehmenshistorische Quelle', Zeitschrift für Unternehmensgeschichte, 40: 158-79

Spoerer, Mark (1996) Von Scheingewinnen zum Rüstungsboom: Die Eigenkapitalrentabilität der deutschen Industrieaktiengesellschaften 1925-1941, Stuttgart: Steiner

Statistisches Jahrbuch für das Deutsche Reich. Ed. by Statistisches Reichsamt, Berlin:

Schmidt, various issues 
Teichova, Alice, Terry Gourvish and Agnes Pogány (eds) (1994) Universal Banking in the Twentieth Century: Finance, Industry and the State in North and Central Europe, Aldershot: Elgar

Temin, Peter (1991) 'Soviet and Nazi economic planning in the 1930s', Economic History Review, 44: 573-95

Tetzlaff, Oskar, Karl E. Moessner and Josef M. Kreuter (1927) Die Steuerbelastung der Deutschen Industrie 1913 und 1925, Berlin: Reichsverband der Deutschen Industrie Tilly, Richard (1995) 'Banks and Industry: Lessons from History', in idem and Paul J.J. Welfens (eds) European Economic Integration as a Challenge to Industry and Government. Contemporary and Historical Perspectives on International Dynamics, Berlin et al.: Springer, pp. 397-435

Walb, Ernst (1930) 'Die steuerrechtliche und steuertechnische Behandlung der Abschreibung in ihrer Beziehung zur Kapitalbildung', in Gerhard Colm and Hans Neisser (eds) Kapitalbildung und Steuersystem, Berlin: Hobbing, pp. 385-424 
Table 1: Stylized Layout of the German Disclosed and Tax Balance Sheets, 1931-1965

Assets

Liabilities

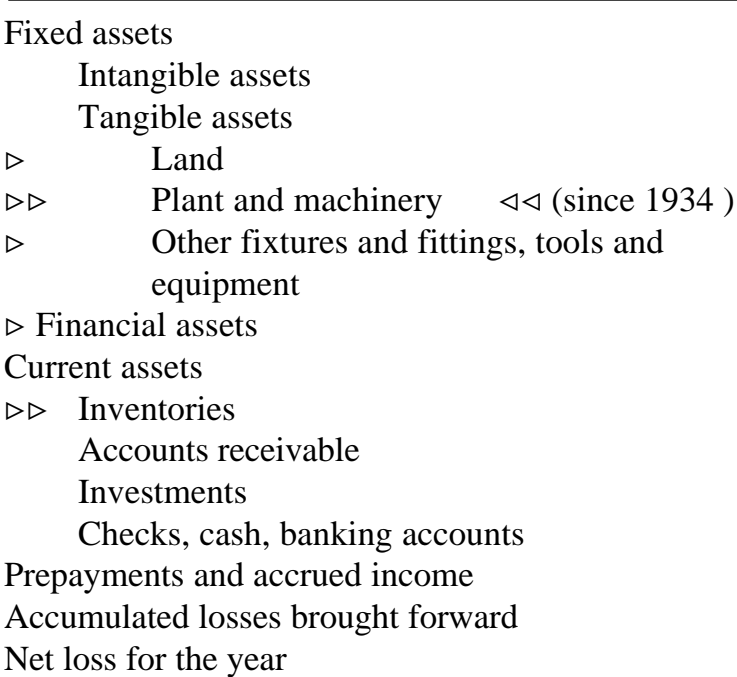

Capital stock

Subscribed capital

Legal reserve

Revenue reserves

Accrued liabilities

$\triangleright \quad$ Provisions for pensions

$\triangleright \triangleright \quad$ Other provisions

Liabilities

$\triangleright$ Loans $\triangleleft$

Other liabilities

Deferred income

Retained profits brought forward

Net income for the year

Balance sheet total

Balance sheet total

Notes: $\triangleright$ under- (assets) or overvaluation (liabilities) admissible in disclosed balance sheet ( $\triangleright$ strong impact), $\triangleleft$ under- (assets) or overvaluation (liabilities) admissible in tax balance sheet ( $\triangleleft$ strong impact). Throughout this article I use 'profit' as a synomym for 'net income for the year'.

Table 2: The Scope for Undervaluation of Assets in German Balance Sheets, 1884-1965

\begin{tabular}{|l|c|c|}
\hline Item & minimum book value & maximum book value \\
\hline $\begin{array}{l}\text { tangible assets, } \\
\text { securities and commodities without } \\
\text { (stock) market prices }\end{array}$ & $1 \mathrm{RM}$ per item & costs of acquisition or production \\
\hline $\begin{array}{l}\text { participating interests, } \\
\text { securities and commodities with } \\
\text { (stock) market prices }\end{array}$ & $1 \mathrm{RM}$ per item & lower of cost or market \\
\hline
\end{tabular}

Sources: Rosendorff (1932: 77), Hanf (1978).

Table 3: The Disclosed Balance Sheet of P. Beiersdorf \& Co. AG, Hamburg

Assets

Fixed assets

Current assets
$31 \mathrm{Dec}, 1934$

7 Subscribed capital

9,445,384 Legal reserve

Revenue reserves

Provisions

Other liabilities

Net income for the year

9,445,391 Balance sheet total

Balance sheet total

Note: layout slightly simplified.

Source: Handbuch der deutschen Aktiengesellschaften (1935: 2387).
Liabilities

$9,445,391$ 
Table 4: Balance Sheet Items of Hoesch AG, Dortmund (mio. RM)

\begin{tabular}{|l|r|r|r|r|}
\hline & $1935 / 36$ & $1936 / 37$ & $1937 / 38$ & $1938 / 39$ \\
\hline (i) $\Delta$ Revenue reserves & 0 & 0 & 0 & 650,000 \\
(ii) $\Delta$, ,Rückstellungen I“ & $-258,066$ & $9,781,228$ & $8,782,308$ & $7,955,326$ \\
(iii) $\Delta$, Rückstellungen II“ & 48,293 & $-200,946$ & 53,909 & 96,328 \\
(iv) Net income, disclosed & $3,668,966$ & $5,118,479$ & $6,445,072$ & $6,118,877$ \\
(v) Dividends & $3,563,000$ & $5,090,000$ & $6,108,000$ & $6,108,000$ \\
(vi) Net income, tax audit & $8,993,033$ & $18,829,755$ & $19,394,787$ & $22,985,734$ \\
\hline
\end{tabular}

Notes: lines (i) to (iii) change to previous year. Subscribed capital and legal reserves remained unchanged. The financial year ran from July to June. Rückstellungen are provisions.

Sources: (i) to (v) Handbuch der deutschen Aktiengesellschaften (1938: 6542, 1943: 1208), (vi) Hoesch-Archiv, Konzernprüfung V.

Table 5: Financial Ratios Calculated from Disclosed and from Tax Balance Sheets, Mitteldeutsche Stahlwerke AG, Berlin (in per cent)

\begin{tabular}{|l|c|c|c|c|c|c|c|c|}
\hline & \multicolumn{2}{|c|}{$\begin{array}{c}\text { equity to } \\
\text { balance sheet total }\end{array}$} & \multicolumn{2}{c|}{$\begin{array}{c}\text { equity to } \\
\text { fixed assets }\end{array}$} & \multicolumn{2}{c|}{$\begin{array}{c}\text { net income } \\
\text { to turnover }\end{array}$} & \multicolumn{2}{c|}{$\begin{array}{c}\text { net income } \\
\text { to equity }\end{array}$} \\
\hline Financial year & disclosed & tax & disclosed & tax & disclosed & tax & disclosed & tax \\
\hline $1926 / 27$ & 54.76 & 55.77 & 107.74 & 131.71 & 3.79 & 1.78 & 6.74 & 2.94 \\
$1927 / 28$ & 55.61 & 49.86 & 109.80 & 127.66 & 3.97 & 3.08 & 6.63 & 5.64 \\
$1928 / 29$ & 54.85 & 49.44 & 115.58 & 136.23 & 3.86 & 3.58 & 7.50 & 7.13 \\
$1929 / 30$ & 56.04 & 51.10 & 112.64 & 133.07 & 3.48 & 1.60 & 5.63 & 3.13 \\
$1930 / 31$ & 54.71 & 45.10 & 116.25 & 118.71 & 0.26 & -10.68 & 0.29 & -14.87 \\
$1931 / 32$ & 54.68 & 47.78 & 117.90 & 124.63 & n.a. & 1.67 & 0.19 & 1.69 \\
$1932 / 33$ & 54.89 & 50.50 & 124.54 & 133.28 & n.a. & 5.32 & 0.58 & 4.35 \\
$1933 / 34$ & 35.67 & 32.57 & 118.16 & 108.32 & n.a. & 4.53 & 3.55 & 6.66 \\
$1934 / 35$ & 37.29 & 40.47 & 124.74 & 132.79 & n.a. & 7.18 & 5.29 & 14.03 \\
$1935 / 36$ & 36.02 & 45.75 & 139.89 & 162.06 & n.a. & 7.50 & 7.17 & 18.45 \\
$1936 / 37$ & 35.00 & 50.37 & 166.98 & 188.63 & n.a. & n.a. & 17.64 & 24.82 \\
$1937 / 38$ & 32.63 & 50.13 & 149.56 & 198.19 & n.a. & 11.17 & 21.59 & 16.07 \\
$1938 / 39$ & 32.06 & 53.87 & 159.92 & 207.84 & n.a. & 16.95 & 13.80 & 24.84 \\
\hline
\end{tabular}

Notes: The variables are defined as in Table 1 (equity = capital stock + retained profits - accumulated losses). The financial year ran from October to September.

Sources: Handbuch der deutschen Aktiengesellschaften, various issues, Sächsisches Hauptstaatsarchiv, Mitteldeutsche Stahlwerke, Nos 12.323, 12.366-12.368. 
Table 6: Profits According to Disclosed and Tax Balance Sheets, Fried. Krupp AG, Essen (mio. RM)

\begin{tabular}{|l|c|c|c|}
\hline Financial year & $\begin{array}{c}\text { disclosed } \\
\text { net income } \\
\text { (i) }\end{array}$ & $\begin{array}{c}\text { net income as of } \\
\text { tax balance sheets } \\
\text { (ii) }\end{array}$ & $\begin{array}{c}\text { (i) in per } \\
\text { cent of (ii) } \\
\text { (iii) }\end{array}$ \\
\hline $1933 / 34$ & $6,651,601$ & $10,278,940$ & 64.7 \\
$1934 / 35$ & $9,689,548$ & $57,216,392$ & 16.9 \\
$1935 / 36$ & $14,354,206$ & $76,094,302$ & 18.9 \\
$1936 / 37$ & $16,226,877$ & $88,657,222$ & 18.3 \\
$1937 / 38$ & $21,111,743$ & $97,071,632$ & 21.7 \\
$1938 / 39$ & $22,705,615$ & $60,099,825$ & 37.8 \\
$1939 / 40$ & $10,719,666$ & $21,372,476$ & 50.2 \\
$1940 / 41$ & $10,894,132$ & $111,555,216$ & 9.8 \\
$1941 / 42$ & $10,115,320$ & a 55,617,746 & 18.2 \\
$1942 / 43$ & 780,191 & a36,956,977 & 2.1 \\
\hline $1933 / 34-40 / 41$ & $112,353,388$ & $522,346,005$ & 21.5 \\
\hline
\end{tabular}

Note: a As final tax assessment was pending, these figures should be regarded as lower limits. The financial year ran from October to September.

Source: Historisches Archiv Krupp, WA 40/339, p. 10.

Table 7: Profit-to-Equity Ratio According to Disclosed and Tax Balance Sheets, 1925-29 and 1933-41 (in per cent)

\begin{tabular}{|l|l|r|r|r|r|r|r|r|r|r|}
\hline & & & \multicolumn{3}{|c|}{ Disclosed Data } & \multicolumn{4}{|c|}{ Tax Data } \\
\cline { 5 - 10 } Period & Industry Aggregate & $\mathrm{n}$ & $\pi_{\mathrm{D}}$ & $\begin{array}{r}\sigma_{\mathrm{D}} \\
(\mathrm{iii})\end{array}$ & $\begin{array}{r}\mathrm{r}_{\mathrm{D}} \\
(\mathrm{iv})\end{array}$ & $\begin{array}{r}\mathrm{t}_{\mathrm{D}} \\
(\mathrm{v})\end{array}$ & $\begin{array}{r}\pi_{\mathrm{T}} \\
(\mathrm{vi})\end{array}$ & $\begin{array}{r}\sigma_{\mathrm{T}} \\
(\mathrm{vii})\end{array}$ & $\begin{array}{r}\mathrm{r}_{\mathrm{T}} \\
(\mathrm{viii})\end{array}$ & $\begin{array}{r}\mathrm{t}_{\mathrm{T}} \\
(\mathrm{ix})\end{array}$ \\
\hline $1925-29$ & total industry & 637 & 6.03 & 8.91 & -0.03 & -0.81 & 9.40 & 14.48 & -0.05 & -1.32 \\
and 1933-41 & capital goods & 405 & 6.10 & 9.18 & -0.03 & -0.53 & 10.68 & 16.36 & -0.07 & -1.33 \\
& consumer goods & 232 & 5.92 & 8.43 & $*_{-}-0.13$ & -2.06 & 7.18 & 10.07 & -0.10 & -1.55 \\
\hline $1925-29$ & total industry & 175 & 3.92 & 7.32 & 0.01 & 0.15 & 2.84 & 9.79 & -0.05 & -0.65 \\
& capital goods & 107 & 3.47 & 6.57 & 0.08 & 0.79 & 2.00 & 8.99 & -0.02 & -0.18 \\
& consumer goods & 68 & 4.64 & 8.36 & $* *-0.33$ & -2.85 & 4.15 & 10.88 & -0.23 & -1.88 \\
\hline $1933-35$ & total industry & 142 & 1.41 & 10.12 & 0.03 & 0.40 & 4.87 & 16.48 & 0.00 & -0.02 \\
& capital goods & 95 & 1.46 & 9.74 & 0.04 & 0.41 & 3.93 & 18.01 & 0.02 & 0.19 \\
& consumer goods & 47 & 1.32 & 10.96 & 0.00 & 0.02 & 6.79 & 12.81 & -0.19 & -1.29 \\
\hline $1936-41$ & total industry & 320 & 9.24 & 7.84 & -0.10 & -1.79 & 15.00 & 13.47 & -0.08 & -1.35 \\
& capital goods & 203 & 9.65 & 8.67 & -0.12 & -1.76 & 18.41 & 14.86 & $*-0.14$ & -2.05 \\
& consumer goods & 117 & 8.52 & 6.11 & -0.02 & -0.24 & 9.10 & 7.69 & 0.07 & 0.70 \\
\hline
\end{tabular}

Notes: Size measured by equity (see note to Table 8). $\mathrm{n}$ - pairs of commercial and tax balance sheets in sample, $\pi_{\mathrm{D}}, \pi_{\mathrm{T}}$ - rates of return on equity, $\sigma_{\mathrm{D}}, \sigma_{\mathrm{T}}$ - standard deviation of rates of return, $\mathrm{r}_{\mathrm{D}}, \mathrm{r}_{\mathrm{T}}$ - correlation coefficients (Pearson), t - t-statistic. * (**) significant on 5 (1) per cent level.

Source: Spoerer (1996: 158). 
Table 8: Regression Results on Misstating Profits in the Disclosed Balance Sheet, 1936-41

\begin{tabular}{lccc}
\hline & $(1)$ & $(2)$ & $(3)$ \\
\hline mean of dependent & -6.48 & -6.48 & -6.48 \\
variable & -22.15 & $-23.13 *$ & -2.80 \\
constant & $(-1.99)$ & $(-2.12)$ & $(-1.15)$ \\
& 3.01 & $3.28 *$ & $(2.06)$ \\
firm size & $(1.78)$ & & $(1.11)$ \\
& 1.18 & & $-7.82^{* *}$ \\
listed on stock exchange & $(0.51)$ & $-9.08 * * *$ & $(-3.38)$ \\
& $-8.74 * * *$ & $(-4.07)$ & 83 \\
capital goods industry & $(-3.73)$ & 83 & 0.14 \\
& 83 & 0.17 & 0.00 \\
observations & 0.16 & 0.00 & \\
adjusted R & 0.00 & & \\
prob (F-Stat) & & & \\
\hline
\end{tabular}

Notes: the estimated model in (1) is $\pi_{\mathrm{D}}-\pi_{\mathrm{T}}=\alpha+\beta_{1} \log ($ equity $)+\beta_{2}$ listed $+\beta_{3}$ capgoods $+\varepsilon$, in (2) and (3) correspondingly. Note that in (3) both independent variables are dummies. *,**,*** - significant on 5,1 , 0.1 per cent level. The correlation coefficient (Pearson) for equity and tax balance sheet total is 98.4 per cent. 